\title{
Mitral Kapak Replasmanı ve Hipoalbüminemisi Olan Hastada Akciğerin Hayalet Tümörü
}

\author{
Serkan Duyuler'® ${ }^{1}$, Pınar Türker Duyuler ${ }^{\circledR}$, Seçil $\operatorname{Karacan}^{3} \oplus$, Derya Pehlivaner ${ }^{4} \oplus$
}

${ }^{1}$ Acıbadem Ankara Hastanesi, Kardiyoloji, Ankara, Türkiye ${ }^{2}$ Ankara Numune Eğitim ve Araştırma Hastanesi, Kardiyoloji, Ankara, Türkiye ${ }^{3}$ Kent Hastanesi, Radyoloji, İzmir, Türkiye

${ }^{4}$ Gazipaşa Devlet Hastanesi, İç Hastalıkları, Antalya, Türkiye

Serkan Duyuler, Dr. Öğr. Üyesi Pınar Türker Duyuler, Doç. Dr. Seçil Karacan, Uzm. Dr. Derya Pehlivaner, Uzm. Dr.
İletişim:

Dr. Öğr. Üyesi Serkan Duyuler Acıbadem Ankara Hastanesi, Kardiyoloji, Ankara, Türkiye

Tel: +903125934278

E-Posta: serkanduyuler@yahoo.com

Gönderilme Tarihi : 09 Kasım 2015

Revizyon Tarihi ：08 Haziran 2017

Kabul Tarihi : 15 Haziran 2017

\section{ÖZET}

Hayalet (veya buharlaşan) akciğer tümörleri, interlobar fisürde plevral efüzyon birikmesiyle oluşan kardiyovasküler tıpta iyi bilinen durumlardır. Her ne kadar sistolik disfonksiyonu olan hastalarda oluştuğu düşüü̈lse de, bu yazıda sistolik fonksiyonları korunmuş mitral kapak replasmanı yapıımış hipoalbuminemili hastada atipik görünümlü hayalet akciğer tümörü sunulmuştur. Hasta bir yıllık takipte benzer bulgu ve belirtilerle mükerrer hospitalize edilmiştir. Hayalet tümör mevcut diüretik tedavisine albümin eklenmesiyle kaybolmuştur. Hipoalbuminemisi olan ve hayalet tümör şüphesi olan hastalarda tedaviye albümin eklenmesi pahalı ve invazif işlemleri engelleyebilir.

Anahtar sözcükler: Hayalet tümör, mitral kapak replasmanı, hipoalbüminemi

\begin{abstract}
A PHANTOM TUMOR OF THE LUNG IN A PATIENT WITH MITRAL VALVE REPLACEMENT AND HYPOALBUMINEMIA
ABSTRACT

Phantom tumors (or vanishing tumors) of the lung are well known clinical conditions in cardiovascular medicine which result from loculation of a pleural effusion within an interlobar fissure. Although the phantom tumor is generally believed to occur in patients with systolic dysfunctions, here we present a case of an atypical phantom tumor of the lung in a patient with mitral valve replacement, preserved systolic function and hypoalbuminemia. The phantom tumor has disappeared after the inclusion of albumin into the intravenous diuretic treatment. The patient was hospitalized (many/multiple) times with similar signs and symptoms in a one-year follow-up. The addition of albumin to the treatment in a patient with hypoalbuminemia and suspected phantom tumor may prevent expensive and invasive procedures.
\end{abstract}

Keywords: phantom tumor, mitral valve replacement, hypoalbuminemia

nterlobar fissürlerde geçici plevral efüzyon toplanması nadir olmakla birlikte iyi bilinen bir durumdur. Bu sıvı birikimleri sağ hemitoraksta daha sık görülürler ve akciğer grafilerinde kitleyi taklit edebilirler. Bu nedenle hayalet (phantom) tümör veya buharlaşan (vanishing) tümör olarak da isimlendirilebilirler. Daha çok sistolik kalp yetersizliğine bağlı olarak bildirilse de, sistolik fonksiyonların korunduğu diastolik disfonksiyonda ve böbrek yetmezliğine bağlı vakalar da mevcuttur (1). Bu yazıda hipoalbumineminin şiddetlendirdiği, sistolik fonksiyonları korunmuş, mitral ve trikuspit kapak replasmanlı hastada gözlenen atipik görünümlü hayalet tümör olgusu sunulmuştur.

\section{Olgu}

Yirmi dört yaşında kadın hasta son 1 aydır artan nefes darlığı ve halsizlik şikayeti ile kliniğimize başvurdu. Hastanın özgeçmişinde, 6 yıl önce romatizmal mitral darlık nedeniyle mitral kapak replasmanı, 3 yıl önce de trikuspit yetersizliği nedeniyle 
triküspit replasmanı ve perioperatif gelişen AV blok nedeniyle kalıcı kalp pili implantasyonu öyküsü mevcuttu. Fizik muayenesinde, hasta astenik görünümdeydi, nabız 75/dk, kan basıncı 100/50 mmHg, solununum sesleri sağ hemitoraksta sola göre azalmış ve sağ bazalde tek tük ral duyulmaktaydı. Metalik kapak sesleri mevcuttu. Mitral ve triküspit odaklarda 2-3/6 sistolik üfürüm tespit edildi. Eser pretibial ödemi olan hastanın tam kan sayımında hafif mikrositer anemisi mevcuttu. Kan biyokimyasında üre: $29 \mathrm{mg} / \mathrm{dl}$, kreatinin: 0,6 mg/dl, sodyum: $136 \mathrm{mmol} / \mathrm{dl}$, potasyum: 4,2 mmol/dl, kalsiyum:7,6 mg/ dl, albümin:1,6 g/ $\mathrm{dl}$, total protein: 3,7 g/dl idi. Tam idrar tetkikinde protein negatifti. Akciğer grafisinde sağ kostofrenik sinüs kapalı, sağ akciğerde alt-orta zonda düzgün konturlu homojen opasite gözlendi (Şekil 1). Ayrıca kardiyotorasik oranın sağ kalp lehine artışı, triküspit ve mitral kapak protezleri ile abdominal yerleşimli kalıcı kalp pili dikkat çekmekteydi. Hastanın transtorasik ekokardiyografisinde sol ventrikül çap ve sistolik fonksiyonları normal sınırlarda, sol atriyum, sağ atriyum ve sağ ventrikül dilate olarak izlendi. Triküspit ve mitral protez kapaklar fonksiyone olarak değerlendirildi. Ancak mitral kapak üzerinde artmış (maksimum 20, ortalama $12 \mathrm{mmHg}$ ) gradient mevcuttu. Triküspit posizyondaki protezde maksimım 8 , ortalama $4 \mathrm{mmHg}$ gradient mevcuttu.Triküspit pozisyondaki protez nedeniyle sistolik pulmoner arter basıncı tahmini yapılamadı. Sağ ventrikül çıkış yolu akselerasyon zamanı 96 ms olarak ölçüldü ve pulmoner hipertansiyon lehine değerlendirildi. Olası kitle, efüzyon, pömoni veya kanama ayrımını kolaylaştırmak için toraks bilgisayarlı tomografisi (BT) çekildi (Şekil 2). Mevcut

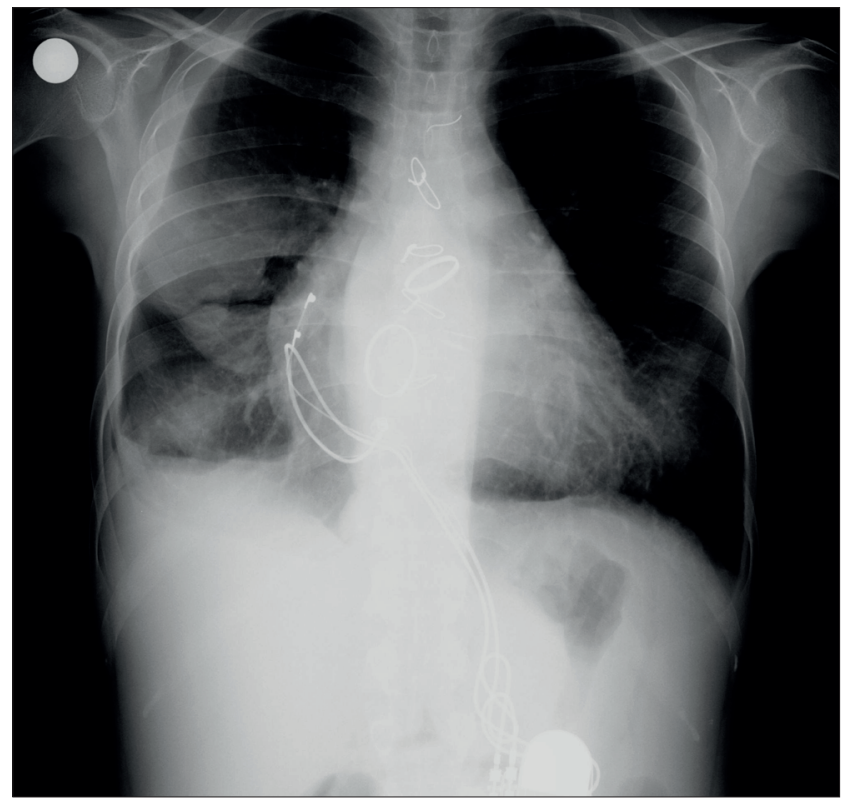

Şekil 1. Sağ akciğer alt-orta zonda düzgün konturlu homojen opasite izlenmektedir. dansitenin lokalize efüzyon ile uyumlu olması üzerine hastanın almakta olduğu oral diüretik dozu arttırılarak intravenöz tedaviye başlandı. İntravenöz furosemide rağmen semptomları iyileşmeyen hastanın sıvısının akciğer grafisinde sebat etmesi üzerine hastanın hipoalbüminemisi de göz önünde bulundurularak albümin replasmanı yapıldı. Hastaya 2 gün süre ile intravenöz albümin ile birlikte intravenöz furosemid tedavisi uygulandı. Albümin değeri $3,1 \mathrm{~g} / \mathrm{dl}$ 'ye yükseldi. Hastanın kontrol akciğer grafisinde daha önce mevcut olan lokalize dansitelerin kaybolduğu gözlendi (Şekil 3). Hastanın akciğer grafisindeki bulgular hipoalbumineminin şiddetlendirdiği, mitral darlığa bağı akciğerin hayalet tümörü olarak değerlendirildi. Hastaya proteinden zengin diyet önerilerek ve mevcut tedavisi düzenlenerek taburcu edildi. Ancak 10 gün sonra kontrole

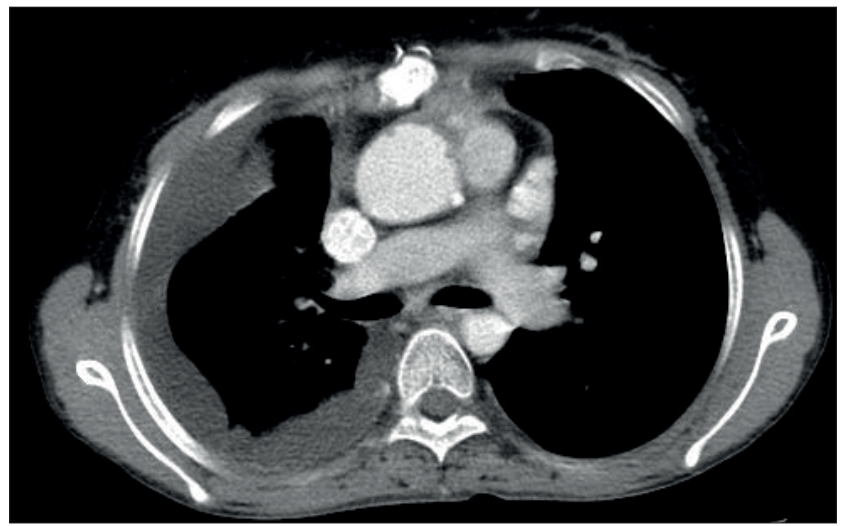

Şekil 2. Hastanın çekilen toraks bilgisayarlı tomografisinde sağ akciğer major fissür içerisinde sIVI dansitesinde loküle koleksiyon görülmektedir.

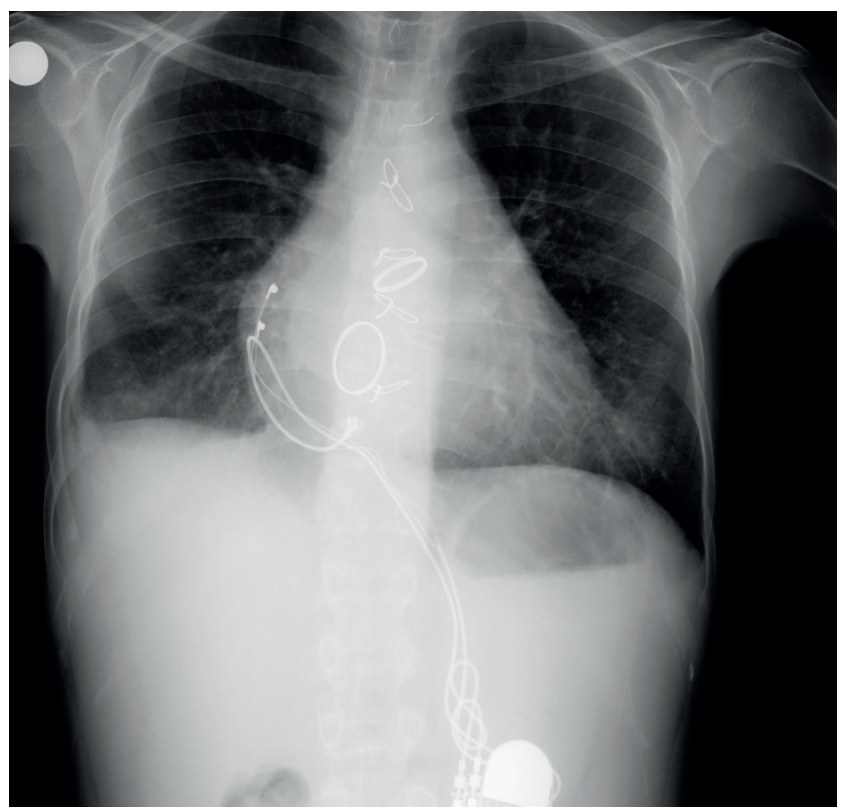

Şekil 3. Albümin ve intravenöz diüretik tedavi sonrası dansite artışı kaybolmuştur. 
gelen hastanın albümin değeri 1,9 g/dl olarak ölçüldü. Hastanın fizik muayenesi ve akciğer filmi bir önceki başvurusu ile benzerdi ve aynı lokalizasyonda hayalet tümör tekrar tespit edildi. Hasta, 1 yıllık takipte toplamda 7 kez benzer bulgu ve şikayetler ile hastanede yatarak tedavi edilmiştir her seferinde hayalet tümör albümin replasmanı olmadan ortadan kaybolmamıştır. Hastanın protein kaçağına yönelik tersiyer merkeze sevki gerçekleştirilmiştir ancak teknik ve sosyo ekonomik nedenilerden dolayı etiyoloji net olarak aydınlatılamamıştır.

\section{Tartışma}

Akciğerin hayalet tümörleri, interlobar fissürlerde oluşan geçici plevral sıvı birkimi olarak tarif edilebilir (2). Görevi her iki plevra yaprağının solunum hareketi sırasında sürtünmesini azaltmak olan plevral sıvı, pariyetal plevra tarafından üretilmektedir. Plevra boşluğunda normal bir insanda yaklaşık $0.26 \mathrm{ml} / \mathrm{kg}$ plevral sıvı bulunur (3). Ancak üretimi ve geri emilimi dinamik bir dengede olan bu sıvı çeșitli durumlarda plevrada birikmektedir. Çoğunlukla plevrada serbest halde bulunan plevral efüzyon, plevral aralıkta yapışıklıklar bulunması durumunda lokule efüzyonlar oluşabilir ve akciğer grafisinde düzgün sınırlı, homojen yapılı kitle görünümü verebilir. Efüzyona sebep olan durumun düzeltilmesiyle hızla kaybolmaları nedeniyle de bu kitle görüntülerine hayalet veya buharlaşan tümörler adı verilmektedir. Bizim hastamızda sağ hemitoraksta yerleşim gösteren lokule efüzyonlar uygun tedavi ile kısa sürede kaybolmuştur. Görünüm olarak tipik hayalet tümörlerden farklı olan hastamızda benzer görünümlere sebep olabilecek patolojilerin ayrımı için toraks BT çekildi.

Konjestif kalp yetersizliği olan hastalarda hipoalbümineminin olası sebepleri karaciğerde yapım yetersizliği, üriner kayıplar ve artmış plazma hacmine bağlı dilüsyonel hipoalbuminemi olarak sıralanabilir. Ancak bu hastalarda gastrointestinal sistemden olabilecek kayıplar da göz ardı edilmemelidir. Hastamızda albüminin yarı ömründen daha kısa sürede tekrar albümin değerlerinde hızlı düşüş

\section{Kaynaklar}

1. Celiker C, Aliyev F, Türkoğlu C, Uzunhasan I. Phantom tumor of the lung in a patient with preserved left ventricular systolic function. Turk Kardiyol Dern Ars. 2009;37:512.

2. Van Gelderen WF. Vanishing pleural fluid collections in cardiac failure simulating lung tumours. Australas Radiol. 1994;38:93-6. olması, karaciğer yetmezliğinin klinik ve biyokimyasal bulgularla desteklenmiyor olması hipoalbüminemi sebebini yapım eksikliğinden çok kayıplara bağlı olabileceğini düşündürmektedir. Tekrarlayan idrar tetkiklerinde idrarda protein tespit edilemeyen hastamızda protein kaybettiren enteropati ön planda düşünülebilecek ayrıcı tanılardandır.

Hayalet tümörlerin oluşumunda en bilinen altta yatan sebep sistolik kalp yetersizliğidir. Diastolik kalp yetersizliğinde, karaciğer ve böbrek yetmezliğinde de tanımlanmış olgular mevcuttur $(1,4)$. Hipoalbuminemi plevral efüzyon oluşmasına neden olmakla birlikte literatürde hayalet akciğer tümörlerinde çok az tanımlanmıştır. Hipoalbuminemi, onkotk basınç farkı nedeniyle öncelikle kendisini periferik ödem olarak gösterir örnek olarak nefrotik sendromlu hastalarda ancak son aşamalarda plevral efüzyon oluşur. Her ne kadar sistolik kalp yetersizliği olmasa da hastamızdaki ciddi mitral darlık nedeniyle sol ventrikül yetersizliği bulguları ortaya çıkmakta olup, artmış pulmoner kapiller hidrostatik basında ek olarak hipoalbumineminin sebep olduğu onkotik basınç azalması zaten efüzyon oluşumu için sınırda olan hemodinamik parametrelerin hızla bozulmasına neden olaktadır. Plazma onkotik basıncının azaldığı hipoalbuminemi mevcudiyeti opere olmasına rağmen yüksek mitral kapak gradienti bulunan hastamızda tek etiyolojik neden olmamakla birlikte hayalet tümör oluşumunda kolaylaştırıcı bir faktör olarak ön plana çıkmaktadır. Hastamızda intrevenöz diüretik tedaviye rağmen gerilemeyen akciğer bulguları tedaviye albümin eklenmesiyle kaybolmuştur. Albümin replasmanıyla plazma onkotik basıncı artışı ile birlikte böbrek tübüllerine furosemidin etkin bir şekilde ulaştırılması da sağlanmaktadır.

Sonuç olarak, hayalet akciğer tümörleri literatürde farklı sebepler ile tanımlanmış bir klinik ve radyolojik fenomendir. İntravenöz diüretik tedaviye rağmen düzelme olmayan hayalet akciğer tümörü şüphesi olan olgularında eğer hipoalbuminemi mevcutsa, pahalı ve invazif girişimlerde bulunmadan önce tedaviye albümin eklenmesi akılcı olacaktır.

3. Agostoni E, Zocchi L. Pleural liquid and its exchanges. Respir Physiol Neurobiol. 2007;159:311-23. [CrossRef]

4. Ganesh Athappan, Venkatesh K Ariyamuthu, V.K. Rajamani. Phantom Tumor of the Lung. Internet Journal of Cardiology. 2007;5:7. 